\title{
Country mapping: Kenya
}

\author{
Francis Obare \\ Population Council \\ Wilson Liambila \\ Population Council \\ Harriet Birungi \\ Population Council \\ Eseoise Itombra \\ Heather Clark \\ Population Council
}

See next page for additional authors

Follow this and additional works at: https://knowledgecommons.popcouncil.org/departments_sbsr-rh

Part of the Demography, Population, and Ecology Commons, Family, Life Course, and Society Commons, International Public Health Commons, Maternal and Child Health Commons, Obstetrics and Gynecology Commons, and the Women's Health Commons How does access to this work benefit you? Let us know!

\section{Recommended Citation}

Obare, Francis, Wilson Liambila, Harriet Birungi, Eseoise Itombra, Heather Clark, and Saumya RamaRao. 2012. "Country mapping: Kenya," Progesterone Vaginal Ring Technical Report. New York: Population Council. 


\section{Authors}

Francis Obare, Wilson Liambila, Harriet Birungi, Eseoise Itombra, Heather Clark, and Saumya RamaRao 


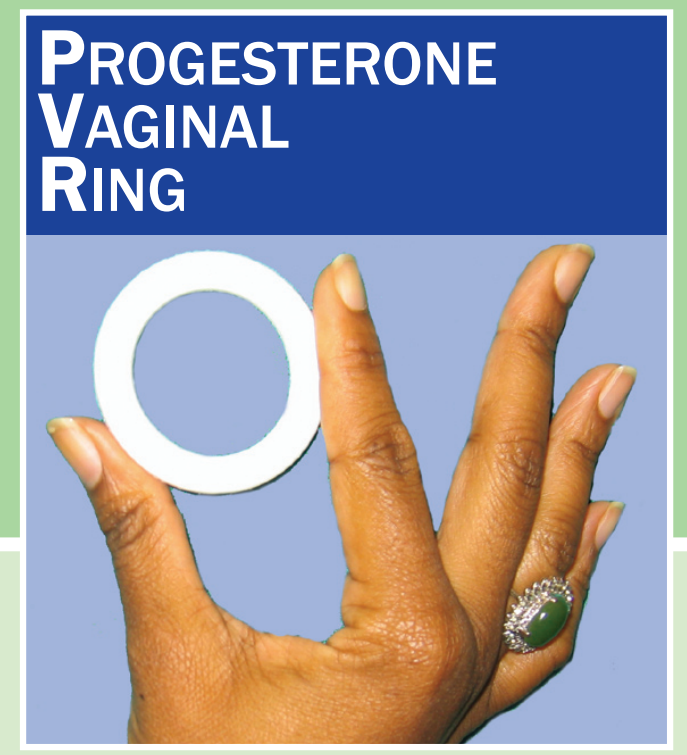

\section{COUNTRY MAPPING: KENYA}



FRANCIS OBARE WILSON LIAMBILA HARRIET BIRUNGI ESEOISE ITOMBRA HEATHER CLARK SAUMYA RAMARAO 


\section{Population Council}

The Population Council confronts critical health and development issues-from stopping the spread of HIV to improving reproductive health and ensuring that young people lead full and productive lives. Through biomedical, social science, and public health research in 50 countries, we work with our partners to deliver solutions that lead to more effective policies, programmes, and technologies that improve lives around the world. Established in 1952 and headquartered in New York, the Council is a nongovernmental, nonprofit organization governed by an international board of trustees.

Population Council

One Dag Hammarskjold Plaza

New York, NY 10017

www.popcouncil.org

\section{Acknowledgments}

This material is for a research project funded by the Bill \& Melinda Gates Foundation. The information contained within does not necessarily reflect positions or policies of the Bill \& Melinda Gates Foundation.

(c) 2012 The Population Council, Inc. 


\section{TABLE OF CONTENTS}



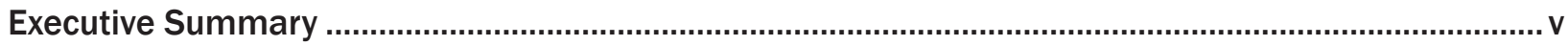

Introduction

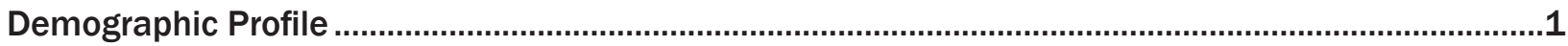

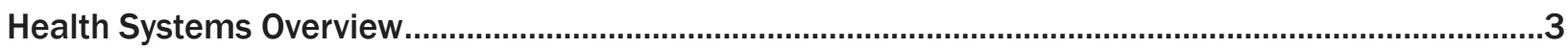

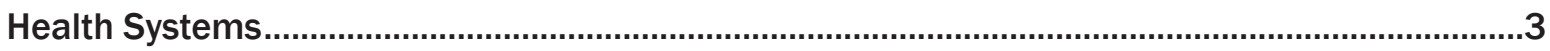

Family Planning and Reproductive Health Policy Context .................................................................

Family Planning and Reproductive Health Program Context .............................................................5

Healthcare Utilization Patterns ..................................................................................................



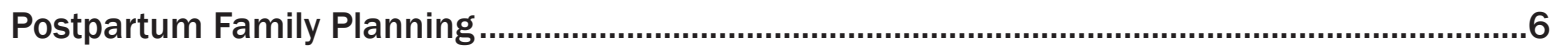

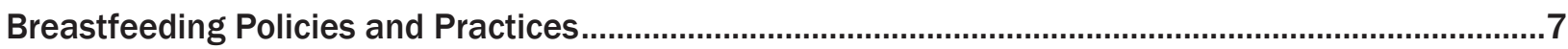

Securing Contraceptive Commodities and Getting Them to Market...................................................

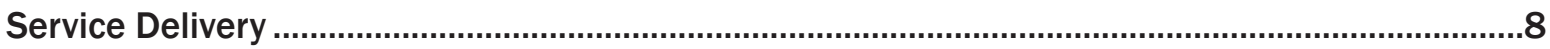

Support for the PVR

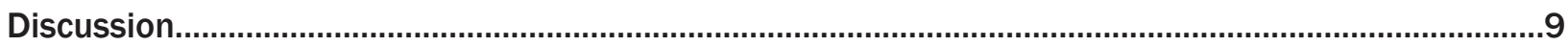

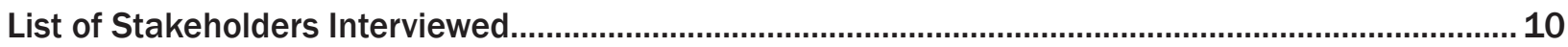

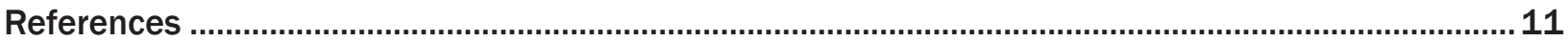




\section{ACRONYMS}

\begin{tabular}{|c|c|c|c|}
\hline AIDS & Acquired Immunodeficiency Syndrome & LAM & Lactational Amenorrhea Method \\
\hline \multirow[t]{2}{*}{ APHRC } & African Population and Health Research & LAPM & Long-Acting or Permanent Method \\
\hline & Center & MDGs & Millennium Development Goals \\
\hline BBT & Basal Body Temperature & $\mathrm{MOH}$ & Ministry of Health \\
\hline CBS & Central Bureau of Statistics & MOMS & Ministry of Medical Services \\
\hline CHEW & Community Health Extension Worker & MOPHS & Ministry of Public Health and Sanitation \\
\hline $\mathrm{CHW}$ & Community Health Worker & MYWO & Maendeleo ya Wanawake Organization \\
\hline $\mathrm{COC}$ & Combined Oral Contraceptives & NCPD & National Council for Population and \\
\hline CPR & Contraceptive Prevalence Rate & & Development \\
\hline DHS & Demographic and Health Surveys & NET-EN & Norethisterone Enanthate \\
\hline DMPA & Depot Medroxyprogesterone Acetate & NFPP & National Family Planning Policy \\
\hline DRH & Division of Reproductive Health & NGO & Nongovernmental Organization \\
\hline FAM & Fertility Awareness-based Methods & NHSSP & National Health Sector Strategic Plan \\
\hline FIGO & $\begin{array}{l}\text { International Federation of Gynecology and } \\
\text { Obstetrics }\end{array}$ & OHERS & $\begin{array}{l}\text { Organization for Health, Education, and } \\
\text { Research Services }\end{array}$ \\
\hline \multirow[t]{2}{*}{ ICPD } & $\begin{array}{l}\text { Human Immunodeficiency Virus } \\
\text { International Conference on Population }\end{array}$ & PPIUCD & $\begin{array}{l}\text { Postpartum Intrauterine Contraceptive } \\
\text { Device }\end{array}$ \\
\hline & and Development & PSI & Population Services International \\
\hline \multirow[t]{2}{*}{ IPPF } & International Planned Parenthood & PVR & Progesterone Vaginal Ring \\
\hline & Federation & SDM & Standard Days Method \\
\hline IUCD & Intrauterine Contraceptive Device & TDM & TwoDay Method $®$ \\
\hline KDHS & Kenya Demographic and Health Survey & UN & United Nations \\
\hline KEPH & Kenya Essential Package for Health & UNFPA & United Nations Population Fund \\
\hline KfW & $\begin{array}{l}\text { Kreditanstalt für Wiederaufbau (German } \\
\text { Development Bank) }\end{array}$ & USAID & $\begin{array}{l}\text { United States Agency for International } \\
\text { Development }\end{array}$ \\
\hline KNBS & Kenya National Bureau of Statistics & WBTi & World Breastfeeding Trends Initiative \\
\hline KOGS & $\begin{array}{l}\text { Kenya Obstetrical and Gynaecological } \\
\text { Society }\end{array}$ & WHO & World Health Organization \\
\hline
\end{tabular}

KURHI Kenya Urban Reproductive Health Initiative 
It is estimated that 222 million women in the developing world have an unmet need for contraception. The high level of unmet need is partly due to the limited use of contraception by women during the first six to 12 months postpartum and high discontinuation rates with about half of all users abandoning their methods six months after adoption. New methods that offer greater ease of use, are women-controlled, and do not require significant health infrastructure or medical provider involvement for service delivery have the potential to increase family planning uptake during the postpartum period and reduce discontinuation rates. One such method is the progesterone vaginal ring (PVR), a user-controlled, mid-acting contraceptive that, according to clinical trial data, is safe and effective for breastfeeding women.

The Population Council has embarked on a threeyear project to explore the acceptability of the PVR among women in sub-Saharan Africa and to develop a strategic plan for its introduction. Between February and May 2012, assessments were undertaken in Kenya to map the landscape of family planning programs and new contraceptive technologies, identify national priorities, and assess the level of interest in the PVR among stakeholders in order to inform the design of appropriate pre-introductory activities. The assessments involved: (1) review of Demographic and Health Surveys (DHS) data; (2) desk review of documents, project reports and policy guidelines; and (3) key informant interviews with representatives of government, regulatory, and development agencies; social marketing organizations; research institutions; manufacturers/distributors; the community; advocacy groups; public/private partnerships; and other organizations providing family planning services.

This report presents the findings of the assessments with specific focus on: (1) the country's demographic profile; (2) the health systems, health policy, and family planning program context; and (3) stakeholder perspectives regarding the PVR. The findings suggest that the introduction of the PVR would fill a gap in the family planning needs of breastfeeding women in Kenya. In addition, there is strong support from stakeholders for future introduction of the PVR. Given the health system challenges (staffing and infrastructure), there is a need for contraceptives that require little training on the part of the provider, do not require a sophisticated health infrastructure, are long-acting and thus do not require monthly visits to a health center, are user-friendly and woman-controlled, and are safe. The PVR addresses all of these concerns and based on the information documented thus far, is likely to be a welcome addition to the existing contraceptive method mix in the country. 



\section{INTRODUCTION}

While the progress made in recent decades in fertility reduction has been impressive, still up to 222 million women in the developing world report an unmet need for contraception (Singh and Darroch 2012). Part of the challenge in addressing current levels of unmet need is the limited use of contraception by women during the first six to 12 months postpartum and the discontinuation rates with about half of all users abandoning their methods six months after adoption. Both issues lead to limited success in effective birth spacing, which then can negatively impact maternal and infant health. New methods are needed that offer greater ease of use, are women-controlled and do not require significant health infrastructure or medical provider involvement for service delivery. One such method is the progesterone vaginal ring (PVR), a user-controlled, mid-acting contraceptive that, according to clinical trial data, is safe and effective for breastfeeding women.

The Population Council has embarked on a threeyear project to explore the acceptability of the PVR among women in sub-Saharan Africa and to develop a strategic plan for its introduction. From February to May 2012 assessments were undertaken in potential study countries-Kenya, Nigeria, and Senegal-to map the landscape of family planning programs and

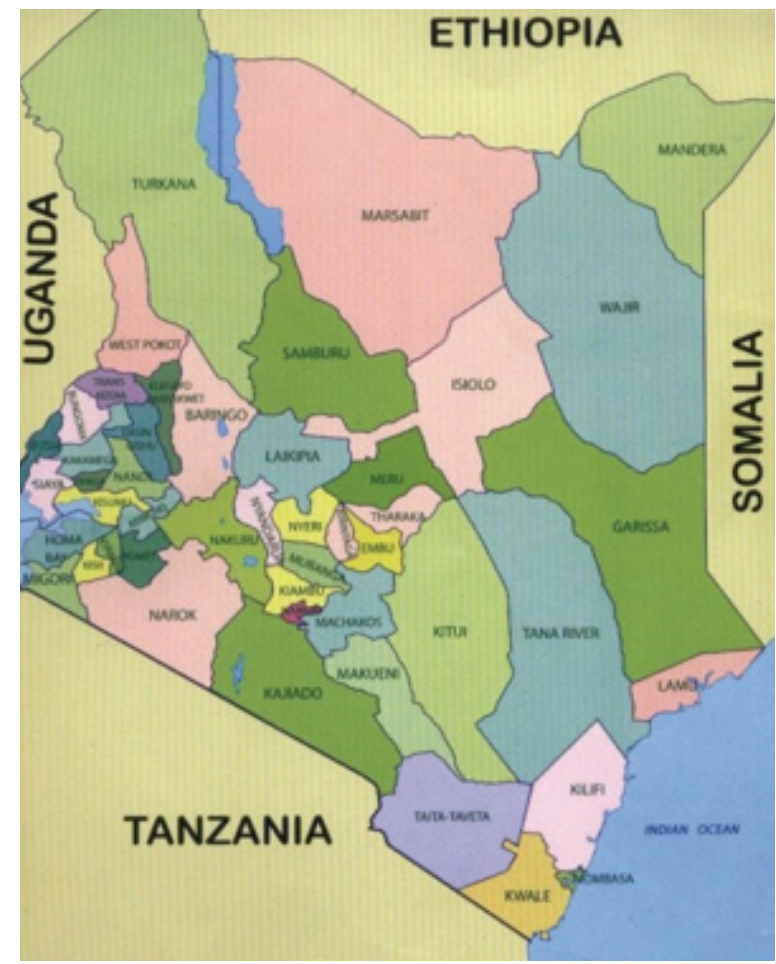

new contraceptive technologies in an effort to identify national priorities and assess the level of interest in the PVR among stakeholders and to design appropriate preintroductory activities. The Council's research teams in each of these countries employed three approaches to develop country-specific reports: review of Demographic and Health Survey (DHS) data, desk review of documents, project reports and policy guidelines, and key informant interviews. Interviews were held with representatives of key government, regulatory, and development agencies; social marketing organizations; research institutions; manufacturers/distributors, the community; advocacy groups; public/private partnerships; and other organizations providing family planning services. This report presents the findings from the stakeholder mapping exercise in Kenya. It begins by describing the country's demographics and unmet need for contraception. It then provides the reproductive health and family planning context as well as the contraceptive program and policy context before concluding with the stakeholder support known thus far and a discussion of what this could mean moving forward with regard to PVR introduction.

\section{DEMOGRAPHIC PROFILE}

The population of Kenya more than doubled over a period of three decades from 10.9 million people in 1969 to 28.7 million by 1999 (CBS 1970; CBS 2001). In 2009, it was 38.6 million and is projected to reach 64 million by 2030 (KNBS 2010). In addition, nearly two-thirds (63\%) of the population is under the age of 25 years ( $64 \%$ of the men and $63 \%$ of the women), while $43 \%$ is aged below 15 years ( $44 \%$ of the men and $42 \%$ of the women) (CBS 2001).

The steady increase in the country's population and the huge proportion of young people are partly due to previous high fertility rates and initial rapid declines in under-five mortality. Kenya had one of the highest fertility rates (8.1 children per woman) in the world as of 1978 (CBS 1981). The fertility rate declined by almost half over a period of two decades to 4.7 children per woman by 1998, one of the most rapid declines ever documented (NCPD and CBS 1999). However, between 1998 and 2008-2009, the fertility rate remained largely unchanged at 4.7 and 4.6 children per woman by 1998 and 2008-2009 respectively (CBS, $\mathrm{MOH}$, and ORC Macro 2004; KNBS and ICF Macro 2010). 
DEMOGRAPHIC SNAPSHOT

\section{POPULATION: 38.6 million}

PROJECTED

POPULATION IN 2030:

GROWTH RATE

TOTAL FERTILITY RATE:

MATERNAL

MORTALITY RATIO:

INFANT

MORTALITY RATE:

$74 / 1,000$

BIRTHS OCCURRING

WITHIN 24 MONTHS

AFTER PRIOR BIRTH:

HIV INCIDENCE:

64 million

$2.8 \%$

4.6 children per woman

$488 / 100,000$

$23 \%$

$6.3 \%$
The country also experienced rapid declines in under-five mortality between the early 1960 s and early 1980s from 211 deaths per 1,000 live births by 1962 to 105 deaths per 1,000 live births by 1989 , but this progress slowed in the early 1990s (Ikamari 2004). Although the under-five mortality rate had declined to 74 deaths per 1,000 live births by $2008-2009$, the levels remain unacceptably high. Maternal mortality, on the other hand, declined from 590 maternal deaths per 100,000 live births in 1998 to 414 by 2003 before increasing to 488 by $2008-2009$. HIV prevalence among adults aged $15-49$ years remained fairly unchanged over a period of five years at $6.7 \%$ in 2003 and $6.3 \%$ in 2008-2009 [CBS, MOH, and ORC Macro 2004; KNBS and ICF Macro 2010).

The Kenya government recognizes that sexual and reproductive health care, including family planning information and services, is a key intervention area for improving the health of women, men, and children. The country's demographic patterns (rapid population growth, high fertility rates, and high levels of maternal and under-five mortality) are therefore likely to put a heavy demand on reproductive health services, including family planning.

Kenya's contraceptive prevalence rate (CPR)-the percentage of currently married women of reproductive age (15-49 years) using any method of family planning-increased more than five times from $7 \%$ in 1978 to $39 \%$ in 1998 , which corresponds to the period when fertility rates declined by almost half (KNBS 2010; CBS 1981). The CPR stalled at 39\% between 1998 and 2003 before increasing to $46 \%$ by $2008-2009$ CBS 1981; NCPB, CBS and MI 1999; CBS, MOH, and ORC Macro 2004). Over the same period, the proportion of currently married women who would like to delay or limit childbearing increased from $72 \%$ to $76 \%$ (Table 1 ). The level of unmet need for family planning-the percentage of currently married women who either do not want any more children or want to wait two or more years before having another child but are not using contraceptionwas about $25 \%$ (from $24 \%$ in 1998 to $26 \%$ in 2008 2009; see Table 1). The indicators in Table 1 show that over the years, women on average desire fewer children than they actually give birth to.

While competing health program and funding priorities may have contributed to the lack of significant progress in fertility and family planning indicators noted in Table 1 (Askew et al. 2009), the Kenya government embarked on deliberate and conscious efforts to reposition family planning in the national development agenda described in the next section.

TABLE 1: KENYA FERTILITY AND FAMILY PLANNING INDICATORS

\begin{tabular}{lrrrr}
\hline & $\begin{array}{r}\text { TOTAL } \\
\text { FERTILITY } \\
\text { RATE }\end{array}$ & $\begin{array}{r}\text { TOTAL } \\
\text { WANTED }\end{array}$ & $\begin{array}{r}\text { WOULD LIKE TO } \\
\text { DELAY OR LIMIT } \\
\text { FUIILITY RATE }\end{array}$ & $\begin{array}{r}\text { UNMET NEED } \\
\text { FOR }\end{array}$ \\
\hline 1998 & 4.7 & 3.5 & $72 \%$ & $24 \%$ \\
2003 & 4.9 & 3.6 & $73 \%$ & $25 \%$ \\
$2008-09$ & 4.6 & 3.4 & $76 \%$ & $26 \%$ \\
\hline
\end{tabular}

SOURCE: Kenya Demographic and Health surveys 1998, 2003, 2008-09 


\section{HEALTH SYSTEMS OVERVIEW}

\section{Health Systems}

The major healthcare providers in Kenya, the Ministry of Public Health and Sanitation and the Ministry of Medical Services, operate over half of all health facilities around the country. These public health facilities remain the major source of family planning and reproductive health services. Fifty-seven percent of women obtain a form of modern contraception from a public health facility, with the rest obtaining methods from private health facilities (36\%) and other sources such as mobile clinics, community-based distributors, local shops, and friends and family (6\%).
The second National Health Sector Strategic Plan (NHSSP II) of 2005-2010 outlined six levels of health service delivery in the country under the Kenya Essential Package for Health (KEPH) (Republic of Kenya $\mathrm{MOH}$ 2005). These include the community (Level 1); dispensaries and clinics (Level 2); health centers, maternity and nursing homes (Level 3); primary, subdistrict, district, and mission hospitals (Level 4); secondary and provincial hospitals (Level 5); and tertiary hospitals (Level 6). Table 2 summarizes the family planning services delivered at each level as well as the available service providers.

Family planning services are also provided through private pharmacies and social marketing programs. According to the National Family Planning Guidelines for Service Providers, private pharmacies should coun-

TABLE 2: LEVELS OF FAMILY PLANNING SERVICE DELIVERY IN KENYA

\begin{tabular}{|c|c|c|}
\hline LEVEL & SERVICE PROVIDERS & FAMILY PLANNING SERVICES \\
\hline $\begin{array}{l}\text { LEVEL 1: } \\
\text { Community }\end{array}$ & $\begin{array}{l}\text { - Community health workers (CHWs) } \\
\text { - Community health extension workers } \\
\text { (CHEWs) } \\
\text { - Community midwives }\end{array}$ & $\begin{array}{l}\text { - Family planning counseling } \\
\text { - Provision of condoms } \\
\text { - Referral for other methods }\end{array}$ \\
\hline $\begin{array}{l}\text { LEVEL 2: } \\
\text { Dispensaries } \\
\text { and clinics }\end{array}$ & $\begin{array}{l}\text { - Nurse/midwife } \\
\text { - Public health technician } \\
\text { - CHEWs }\end{array}$ & $\begin{array}{l}\text { - Family planning counseling } \\
\text { - Provision of condoms, pills, injectables } \\
\text { - Provision of implants and IUCD } \\
\text { depending on training } \\
\text { - Referral for other methods }\end{array}$ \\
\hline $\begin{array}{l}\text { LEVEL 3: } \\
\text { Health centers, } \\
\text { maternity and } \\
\text { nursing homes }\end{array}$ & $\begin{array}{l}\text { - Doctor (outreach) } \\
\text { - Clinical officer } \\
\text { - Nurse/midwife } \\
\text { - Public health technician } \\
\text { - CHEWs }\end{array}$ & $\begin{array}{l}\text { - Family planning counseling } \\
\text { - Provision of condoms, pills, injectables } \\
\text { - Provision of implants and IUCD } \\
\text { depending on training } \\
\text { - Provision of bilateral tubal ligation and } \\
\text { vasectomy as outreach } \\
\text { - Referral for other methods }\end{array}$ \\
\hline $\begin{array}{l}\text { LEVEL 4: } \\
\text { Primary, } \\
\text { subdistrict, } \\
\text { district, and } \\
\text { mission hospitals }\end{array}$ & $\begin{array}{l}\text { - Doctors } \\
\text { - Clinical officer } \\
\text { - Nurse/midwife } \\
\text { - Public health officer or technician }\end{array}$ & $\begin{array}{l}\text { - Family planning counseling } \\
\text { - Provision of full range of family } \\
\text { planning methods }\end{array}$ \\
\hline $\begin{array}{l}\text { LEVELS } 5 \text { and 6: } \\
\text { Secondary, } \\
\text { provincial, and } \\
\text { tertiary hospitals }\end{array}$ & $\begin{array}{l}\text { - Doctors (including specialists) } \\
\text { - Clinical officer } \\
\text { - Nurse/midwife }\end{array}$ & $\begin{array}{l}\text { - Family planning counseling } \\
\text { - Provision of full range of family } \\
\text { planning methods }\end{array}$ \\
\hline
\end{tabular}

SOURCE: Division of Reproductive Health (DRH)/Ministry of Public Health and Sanitation (MOPHS). 2010. National Family Planning Guidelines for Service Providers. Nairobi: DRH/MOPHS; pp.38-40.; IUCD: Intrauterine contraceptive device 
sel clients on and provide or sell condoms, pills, injectables, implants, and Standard Days Methods (SDM) (DRH and MOPHS 2010). In addition, they should refer clients for lactational amenorrhea methods (LAM), injection, intrauterine contraceptive device (IUCD), other fertility-based awareness methods (FAM), and sterilization. Social marketing programs are, on the other hand, expected to promote, sell, or refer clients for most of the family planning methods except FAM and sterilization where the guidelines stipulate that they should only refer clients (DRH and MOPHS 2010)

\section{FAMILY PLANNING AND REPRODUCTIVE HEALTH POLICY CONTEXT}

Kenya was the first sub-Saharan African country to establish a national family planning programme (which was regarded as an African success story) through the National Family Planning Policy (NFPP) of 1967 . However, it was not until 1984 that the first population policy-Population Policy Guidelines-was developed. A number of population and health policies have since been put in place especially since the 1994 International Conference on Population and Development (ICPD).

The National Population Policy for Sustainable Development was developed in 2000. The Policy widened the scope for addressing population issues by integrating a domestic Programme of Action of the ICPD. It had the objectives of: (1) improving the standards of living and the quality of life of the people; (2) fully integrating population concerns into the development process; (3) motivating and encouraging Kenyans to adhere to responsible parenthood; (4) promoting the stability of the family; (5) empowering women and eliminating retrogressive socio-cultural practices such as female genital mutilation; and (6) integrating the youth, the elderly, and persons with disabilities into the mainstream in national development (NCPD 2000).

In 2003, the government developed the Adolescent Reproductive Health and Development Policy with one of its key targets being to double the contraceptive prevalence rate among adolescents aged 15-19 and youth aged 20-24 years by 2015 (NCPD and DRH). Since 2005, the government has embarked on deliberate and conscious efforts to reposition family planning in the national development agenda. Key among these efforts was the development of the first National Reproductive Health Policy in 2007 that outlined family planning as one of the priority reproductive health components and recognized that the available family planning methods do not allow for a wide method choice (MOH 2007). The policy's aim was to guide planning, standardization, implementation, and monitoring and evaluation of reproductive health care provided by various stakeholders. The policy allowed the government to incorporate and address key issues such as security of reproductive health commodities, prevention of mother-to-child transmission of HIV, emergency obstetric care, adolescent reproductive health issues, gender-based violence, reproductive health needs of persons with disabilities, and integration of reproductive and HIV health care ( $\mathrm{MOH} 2007)$.

In 2008, the government developed a strategy to increase the uptake of long-acting or permanent methods (LAPMs). One of the areas of focus for the strategy was ensuring a wider availability of method choices through enhanced commodity security, equipment and supplies (MOPHS/DHR 2008). In 2009, the government unveiled a strategy for the period 2009-2015 to guide the implementation of the National Reproductive Health Policy. The objectives of the strategy with respect to family planning are to reduce unmet need, unplanned births, and regional and socioeconomic disparities in the CPR (MOPHS and MOMS 2009).

In 2010, the government issued revised National Family Planning Guidelines for Service Providers that outlined the recommended practices in the provision of family planning services in the country (DRH/ MOPHS 2010). The guidelines further addressed issues relevant for the provision of family planning services including enhancing the functions of community health workers and community-based distributors and male involvement. The government also convened the National Population Leaders' Conference in Nairobi. The conference provided leaders from around the country with an opportunity to: (1) address critical population issues-including repositioning family planning - that affect the quality of life of Kenyans; and (2) shape clear, succinct, and understandable messages about these issues for the general population. 
The government further formulated other development policies that have direct bearing on population and health issues. For instance, following the adoption of the United Nations (UN) Millennium Development Goals (MDGs) in 2000, the government launched MDG-based planning and budgeting

in 2004. The MDGs include targets to be achieved by 2015 in the areas of eradicating poverty and hunger, achieving universal primary education, promoting gender equality, reducing child mortality, improving maternal health, combating HIV/AIDS and other diseases, reducing environmental degradation, and fostering partnerships with international development partners (Republic of Kenya 2005).

Kenya has taken many steps to ensure that reproductive health and family planning are at the center of the national agenda by recognizing the need for expanding contraceptive choice, setting time-based objectives to see improvements in related indicators, and repositioning family planning. The policy environment in Kenya is therefore open to and supportive of new-method introduction.

\section{FAMILY PLANNING AND REPRODUCTIVE HEALTH PROGRAM CONTEXT}

\section{Healthcare Utilization Patterns}

Estimates from the 2008-2009 Kenya Demographic and Health Survey (KDHS) show that whereas 92\% of expectant women in the country receive antenatal care from skilled providers, only $43 \%$ of births occur in health facilities while another $44 \%$ of births are delivered under skilled care (KNBS and ICF Macro 2010). In addition, only $47 \%$ of the mothers report receiving a postnatal check-up after the birth (KNBS and ICF Macro 2010). However, more than threequarters (77\%) of the children aged between 12 and 23 months are fully immunized (KNBS and ICF Macro 2010).

There are wide regional and socioeconomic variations in the use of reproductive health services in the country. For instance, the proportion of women delivering in a health facility is more than twice as high in the urban compared to rural areas (75\% and
$35 \%$, respectively) and more than four times higher among women from the richest compared to those from the poorest households ( $81 \%$ compared to $18 \%$, respectively). It is also more than three times higher in Nairobi compared to North Eastern province (89\% and $17 \%$, respectively). A similar pattern is noted with respect to contraceptive use. In particular, the contraceptive prevalence rate (CPR) in urban areas is 53\% while it is lower in the rural areas (43\%). CPR is also more than twice as high among women from the richest households compared to those from the poorest households (55\% and 20\%, respectively) and more than 16 times higher in Central compared to North Eastern province ( $67 \%$ and $4 \%$, respectively).

\section{Contraceptive Use and Method Mix}

The family planning methods available in Kenya are: (1) hormonal methods: including combined oral contraceptives (COCs); Progestin-only contraceptive pills, Progestin-only injectable contraceptives (DMPA, NETEN); Progestin-only contraceptive implants (Jadelle, Implanon, Zarin, Sino-Implant); and dedicated emergency hormonal contraceptive pills (Postinor2, Pregnon, Smart Lady, ECee2, Truston2); (2) IUCDs: copper-based devices (Copper T380A) and hormonereleasing Intra-Uterine Systems (Mirena LNG-20IUS); (3) voluntary surgical contraception for women (tubal ligation or female sterilization) and men (vasectomy or male sterilization); (4) barrier methods: male and female condoms, diaphragms, cervical caps, and spermicides; although the use of diaphragms, cervical caps and spermicides is negligible; (5) lactational amenorrhoea method (LAM): lack of ovulation which results from exclusive breastfeeding; and (6) FAMs: calendar-based methods such as the Standard Days Method $\circledast($ SDM); symptoms-based methods such as the. TwoDay Method ${ }^{\circledR}$ (TDM), Cervical Mucus or Billings Ovulation Method, Basal Body Temperature (BBT), and Sympto-thermal Method (Cervical Mucus+BBT); and withdrawal or coitus interruptus method (DRH/MOPHS 2010).

Modern family planning methods are the most commonly used contraceptives (by 39\% of currently married women) compared to traditional methods such as rhythm, withdrawal, or folk methods. Over the years, injectables have been the most commonly used modern of family planning methods followed by the pill and female sterilization (Figure 2). The use of 
FIGURE 2: TRENDS IN USE OF SPECIFIC FAMILY PLANNING METHODS

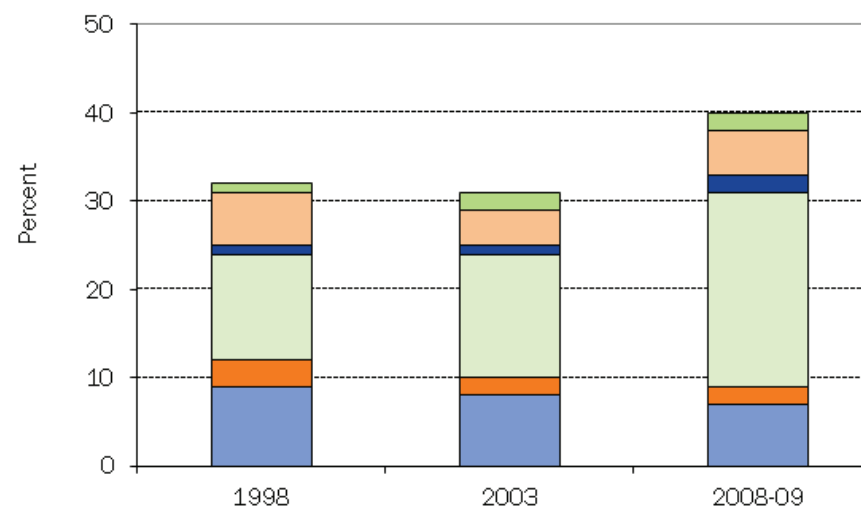

口Pill aIUCD alnjectables

Condoms aFemalesterilization almplants

injectables almost doubled from $12 \%$ in 1998 to $22 \%$ in 2008-09 while the use of pills declined from 9\% to $7 \%$ over the same period (Figure 2). The use of female sterilization, on the other hand, declined from $6 \%$ in 1998 to 4\% in 2003 before slightly increasing to 5\% in 2008-09. Preference for injectables is also evident among married women who are not using contraceptives but intend to use in future: slightly more than half (52\%) prefer injectables, 12\% prefer the pill, 8\% prefer female sterilization, and another $8 \%$ prefer implants.

Sino-Implant was the last contraceptive method to be introduced in Kenya. Experience from its introduction shows that the country of origin/manufacturer is critical in influencing people's perceptions about the product. In addition, experiences from the introduction of other methods such as emergency contraceptives show that products that are user-controlled are quite popular with clients as opposed to those that are solely provided by healthcare workers. The involvement of government officials from the outset of product introduction planning is also critical as is the need for repeat training and technical supervision of service providers during the introduction process (Keesbury et al. 2009; Shauri and Vail 2009). It is also worth noting that the use of and attitudes surrounding hormonal contraception in Kenya appear to be unchanged in light of the recent inconclusive evidence regarding hormonal contraception and the acquisition of HIV (MOPHS 2011).
Since the PVR is a product that is self-inserted into the vagina, the use of other vaginal products may serve as a proxy for its uptake. Products that are inserted into the vagina, such as the diaphragm and menstrual cups, have received mixed reactions in Kenya. For instance, in a study conducted in Mombasa among female sex workers, the diaphragm was found to be an acceptable method with high user satisfaction (Luchters et al. 2007). In contrast, in a study of the acceptability of the menstrual cup in Nairobi, most participants encountered discomfort while some complained that they could feel the cup in their vaginas or some pain at the first attempt (APHRC 2010). There is no literature on the use of tampons in Kenya. However, a study in the United States found that tampon users were more likely to choose the contraceptive vaginal ring than combined oral contraceptive pills.

\section{Postpartum Family Planning}

The level of family planning in the postpartum period remains low in the country with only $25 \%$ of postpartum women using a family planning method compared to the national CPR of 46\% (KNBS and ICF Macro 2010; Gebreselassie, Rutstein, and Mishra 2008). In addition, the level of unmet need for family planning is more than twice as high among postpartum women (68\%) compared to those in the general population (26\%) (KNBS and ICF Macro 2010; Gebreselassie, Rutstein, and Mishra 2008). The postpartum period is also characterized by a limited range of available family planning methods that include LAM, IUCD, sterilization, progestin-only pills, injectables, and condoms, with injectables being the dominant contraceptive method used (Gebreselassie, Rutstein, and Mishra 2008).. The Ministry of Health therefore recognizes the need for family planning information and services during the postpartum period as an integral component of maternal and neonatal care services (DRH/MOPHS 2010). However, programs to strengthen family planning service provision during the postpartum period have to date been donor-driven and implemented on a pilot basis in selected districts (Mwangi et al. 2008; Chebet and Jahonga 2011). These programs have, however, demonstrated substantial improvements in the uptake of family planning in the postpartum period (Mwangi et al. 2008; Chebet and Jahonga 2011). 


\section{BREASTFEEDING POLICIES AND PRACTICES}

With respect to breastfeeding practices, nearly all children under five years of age (97\%) are ever breastfed. In addition, mothers initiate breastfeeding within one hour of birth for $58 \%$ and within one day of birth for $86 \%$ of the children ever breastfed. Forty-two percent of the children are given something other than breast milk (pre-lacteal liquids) during the first three days of life. The most commonly given pre-lacteal liquids include plain water (37\%), sugar or glucose water (27\%), sugar and salt water (23\%), and other milk (13\%). Other pre-lacteal liquids include gripe water (5\%), fruit juice (1\%), infant formula (2\%), and tea/infusions (3\%). The median duration for any breastfeeding is 21 months while the median duration for exclusive breastfeeding is less than one month. The median duration of breastfeeding is longer in rural than in urban areas (21 and 19 months, respectively) and in North Eastern compared to Nairobi province (26 and 15 months, respectively). Ninety-three percent of children under the age of six months are breastfed six times or more in a 24-hour period.

Only $32 \%$ of children under six months of age are exclusively breastfed. This proportion is highest (52\%) for children aged 0-1 month; after 8 months, the proportion of children being exclusively breastfed declines to less than $1 \%$. Therefore, there is a strong case for the progesterone vaginal ring since exclusive breastfeeding is not highly practiced and the hormones in the PVR are natural and therefore will not affect breastfeeding. However, in September 2012, parliament passed a law aimed at promoting exclusive breastfeeding for the first six months and continuous breastfeeding after the introduction of other foods up to a period of 24 months. The law has, however, been criticized for seeking to regulate the marketing, promotion, distribution, and sale of breast milk substitutes rather than promote exclusive breastfeeding (Maina 2012). The government has also formulated several policies aimed at protecting, promoting and supporting optimal infant feeding practices (Republic of Kenya/MOPHS 2012).

\section{SECURING CONTRACEPTIVE COMMODITIES AND GET- TING THEMI TO MARKET}

For many years, the commodities and drug procurement system in Kenya was based on the "push system," or one that anticipates future needs and furnishes products in advance of those needs. However, in the past two years, Kenya has been experimenting with the "pull system," or one that supplies orders that have already been filled. By November 2011, four provinces were piloting the "pull system" while the other four continued to use the "push system."

The current strategic plan (2011-2015) for the Division of Reproductive Health addresses three main priority areas: demand creation, family planning commodity security, and adolescent health. There exists a strategic plan on reproductive health and family planning commodities that emphasizes:

- Regular updating of the commodity procurement plan reflecting Kenya government and donor commitment;

- Timely procurement to ensure a full product pipeline;

- Improvement in technical capacity for forecasting and quantification at the district level; and

- Improvement in district oversight of the supply chain and the commodity information system.

The Pharmacy and Poisons Board of Kenya is responsible for the overall regulation of new drugs and medical devices in Kenya. The board has published a number of guidelines to regulate clinical trials in Kenya

\section{Breastfeeding in Kenya}

Children ever breastfed: $97 \%$

Median duration for any breastfeeding: 21 months

Median duration for exclusive breastfeeding: $<1$ 
TABLE 3: STAKEHOLDERS CONSULTED DURING COUNTRY MAPPING

\begin{tabular}{|c|c|}
\hline STAKEHOLDER TYPE & NAME OF INSTITUTION \\
\hline Government agencies \& policymakers & $\begin{array}{l}\text { Ministry of Public Health and Sanitation-Division of Repro- } \\
\text { ductive Health }\end{array}$ \\
\hline Regulatory \& quality assurance agencies & Pharmacy \& Poisons Board \\
\hline $\begin{array}{l}\text { Private-sector providers (family planning/ } \\
\text { postpartum care) }\end{array}$ & $\begin{array}{l}\text { Organization for Health, Education and Research Services } \\
\text { (OHERS)- Non-governmental organization }\end{array}$ \\
\hline $\begin{array}{l}\text { Public/private partnership for health provider (in- } \\
\text { cluding family planning/postpartum care) }\end{array}$ & $\begin{array}{l}\text { Kenya Urban Reproductive Health Initiative (KURHI-Jipange, } \\
\text { Jhpiego) }\end{array}$ \\
\hline $\begin{array}{l}\text { Other organizations providing family planning/post- } \\
\text { partum care }\end{array}$ & Marie Stopes, IPPF \\
\hline Development agencies & USAID, WHO, UNFPA, KfW \\
\hline Social marketing & Population Services International (PSI) \\
\hline Community representative \& advocacy groups & Maendeleo ya Wanawake Organization (MYWO) \\
\hline Professional associations & $\begin{array}{l}\text { Kenya Obstetrical and Gynaecologcal Society (KOGS) (FIGO- } \\
\text { Affiliate) }\end{array}$ \\
\hline Research institutions & FHI 360 \\
\hline Drug manufacturers/distributors & Bayer East-Africa \\
\hline
\end{tabular}

NOTES: IPPF: International Planned Parenthood Federation; USAID: United States Agency for International Development; WHO: World Health Organization; UNFPA: United Nations Population Fund; KfW: Kreditanstalt für Wiederaufbau (German Development Bank); FIGO: International Federation of Gynecology and Obstetrics.

as well as on the submission of documentation for registration of medical devices and drugs. The Board is also responsible for approving the importation of limited quantities of drugs, including the PVR, into Kenya for the purpose of carrying out research activities.

\section{Service Delivery}

Stakeholders in Kenya were consulted to identify where and how they thought the PVR would be most successfully integrated into the health system. All stakeholders agreed that there should be no parallel systems and that the PVR should be distributed through either the private or public sector. Most participants favored introduction of the PVR through the public sector (6 out of 10). A few stakeholders voiced preference for introduction through the private sector (3 out of 10), and one stakeholder suggested that the nongovernmental organization (NGO) sector would be a good channel. Kenya's policy environment with regard to reproductive health and family planning is supportive of the introduction of new contraceptives regardless of the channel of distribution. 


\section{SUPPORT FOR THE PVR}

The consensus arising from the stakeholder consultations was that the PVR is seen as an important addition to the family planning method mix for postpartum women. Stakeholders would like to learn more about pricing and potential positioning of the product. They also had concerns about whether the product has been registered by the US Food and Drug Administration (which it has not due to the fact that breastfeeding is not as universal or prolonged). Other logistical and practical considerations were also discussed to determine areas that should be addressed for successful introduction of the product. Most emphasized learning from the experience of Sino-Implant, particularly with respect to the country where the product is manufactured, which is critical in influencing people's perception. In addition, recommendations were made to plan for advocacy activities and enlist female gynecologists as advocates to talk about the product in various forums and with women's group leaders. Stakeholders also advocated getting the PVR on the World Health Organization's Essential Commodities List. The potential support for the PVR among users, partners, providers, and community members will be determined through acceptability studies.

\section{STAKEHOLDER RECOMMENDATIONS FOR INTRODUCTION}

1. Find an advocate

2. Develop a dossier of safety and efficacy evidence to help fast-track registration

3. Avoid simultaneous introduction into multiple sectors (public and private)

4. Address any myths and misconceptions

5. State benefits to woman, child and partner

6. Focus on the PVR's ease of use

7. Emphasize pharmacist training if product is to be available over the counter

8. Address question of product pricing

\section{DISCUSSION}

After consideration of how family planning is perceived in Kenya's socio-cultural and political environment and an analysis of the health system infrastructure, it appears that the introduction of the PVR would fill a gap in the family planning needs of breastfeeding women in Kenya. The strong support for future introduction of the PVR and the more immediate acceptability studies the Council is conducting as part of pre-introductory efforts further underscore the potential for the PVR to fill this gap. There is a need for contraceptives that require little training on the part of the provider, do not require a sophisticated health infrastructure; are long-acting and thus do not require monthly visits to a health center, and are user-friendly, woman-controlled, and safe. The PVR addresses all of these concerns and based on the information documented thus far, is likely to be a welcome addition to the existing contraceptive method mix. 


\section{LIST OF STAKEHOLDERS INTERVIEWED}

\begin{tabular}{|c|c|c|}
\hline DATE & ORGANIZATION & PERSON(S) SEEN \\
\hline 02.05 .2012 & Marie Stopes International & $\begin{array}{l}\text { Dr. Edwin Mbugua } \\
\text { Louise Patterson } \\
\text { Dr. Mark Ayallo } \\
\text { Gabrille Appleford } \\
\text { Dr. Cleophas Ondieki }\end{array}$ \\
\hline \multirow[t]{2}{*}{04.05 .2012} & USAID & $\begin{array}{l}\text { Sheila Macharia } \\
\text { Emily Iruguthu }\end{array}$ \\
\hline & Division of Reproductive Health (DRH) & $\begin{array}{l}\text { Dr. Shiphrah Kuria } \\
\text { Dr. Agnes Nakato } \\
\text { Dr. Pamela Godia } \\
\text { Dr. Gathari Ndirangu } \\
\text { John Mwang } \\
\text { Damaris Mwanzia } \\
\text { Anne Njeru }\end{array}$ \\
\hline 11.05.2012 & FHI 360 & Dr. Marsden Solomon \\
\hline 14.05.2012 & Bayer East Africa & $\begin{array}{l}\text { Dr. Bernard Matheka } \\
\text { Mr. Bernard Mutua } \\
\text { Mr. Kuto }\end{array}$ \\
\hline 14.05.2012 & Kfw & Julia Fimpel \\
\hline 15.05.2012 & KURHI-JIPANGE/Jhpiego & $\begin{array}{l}\text { Mr. Nelson Keyonzo } \\
\text { Dr. Janet Omyonga }\end{array}$ \\
\hline 15.05.2012 & PSI & $\begin{array}{l}\text { Anthony Okoth } \\
\text { Joyce Maina-Wanderi } \\
\text { Susan Karimi }\end{array}$ \\
\hline 16.05.2012 & World Health Organization (WHO) & Dr. Joyce Lavussa \\
\hline 21.05.2012 & Kenya Obstetrics and Gynecological Society (KOGS) & Dr. Guyo Jaldesa \\
\hline 21.05.2012 & $\begin{array}{l}\text { Organization for Health, Education and Research Services } \\
\text { (OHERS) }\end{array}$ & $\begin{array}{l}\text { Mrs. Nelly Luchemo } \\
\text { Maureen }\end{array}$ \\
\hline 21.05.2012 & Maendeleo Ya Wanawake Organization (MYWO) & Susan Atieno Chege \\
\hline 22.05 .2012 & The International Planned Parenthood Federation & Dr. Lawrence Oteba \\
\hline 25.05 .2012 & UNFPA & Dr. Stephen Wanyee \\
\hline
\end{tabular}


African Population and Health Research Center (APHRC). 2010. "Attitudes Towards, and Acceptability of, Menstrual Cups as a Method of Managing Menstruation: Experiences of Women and School Girls in Nairobi, Kenya." Policy Brief. Nairobi: APHRC.

Askew, lan, Alex Ezeh, John Bongaarts, and John Townsend. 2009. Kenya's Fertility Transition: Trends, Determinants and Implications for Policy and Programmes. Nairobi: Population Council.

Central Bureau of Statistics (CBS), Ministry of Finance and Planning. 1970. 1969 Population Census. Vol. 4. Nairobi: CBS.

—. 1981. 1979 Population Census. Vol. 2. Nairobi: CBS.

Central Bureau of Statistics (CBS), Ministry of Health (MOH), and ORC Macro. 2004. Kenya Demographic and Health Survey 2003. Calverton, MD: CBS, MOH, and ORC Macro.

Central Bureau of Statistics (CBS) [Kenya], Ministry of Planning and National Development. 2001. Population Distribution by Administrative Areas and Urban Centres, Kenya 1999 Population and Housing Census. Vol. 1. Nairobi: CBS.

Chebet, Kenneth and Ruth Jahonga. 2011. "Experiences with the postpartum intrauterine contraceptive device (PPIUCD) in Eastern Province, Kenya." Paper presented at the International Conference on Family Planning, Dakar, Senegal, 29 November-2 December.

Division of Reproductive Health (DRH)/Ministry of Public Health and Sanitation (MOPHS). 2010. National Family Planning Guidelines for Service Providers. Nairobi: DRH/MOPHS.

Gebreselassie, T., S.O. Rutstein, and V. Mishra. 2008. Contraceptive Use, Breastfeeding, Amenorrhea and Abstinence during the Postpartum Period: An Analysis of Four Countries. Analytical Studies No. 14. Calverton, MD: Macro International Inc.

Ikamari, Lawrence. 2004. "An upsurge in early childhood mortality in Kenya: A search for explanations." African Journal of Health Sciences 11(1-2): 9-20.

Keesbury, Jill, Wilson Liambila, Francis Obare, and Paul Kuria. 2009. Mainstreaming Emergency Contraception in
Kenya: Final Project Report. Nairobi: Population Council and Population Services International.

Kenya National Bureau of Statistics (KNBS). 2010. 2009 Kenya Population and Housing Census, Vol. 1A \& 1C. Nairobi: KNBS.

Kenya National Bureau of Statistics (KNBS) and ICF Macro. 2010. Kenya Demographic and Health Survey 200809. Calverton, MD: KNBS and ICF Macro.

Luchters, S., M.F Chersich, I. Jao, A. Schroth, S. Chidagaya, K. Mandaliya, and M. Temmerman. 2007. "Acceptability of the diaphragm in Mombasa, Kenya: A 6 month prospective study," European Journal of Contraception and Reproductive Health Care Monthly 4(4): 1-9.

Maina, B. 2012. "The Breast Milk Substitutes Law is not about breastfeeding." Available at: http://www.africasciencenews.org/en/index. php?option=com_content $\&$ view=article $\&$ id $=630$ :thebreast-milk-substitutes-law-is-not-about-breastfeeding\&catid=63:health\&ltemid=114 (Accessed: 4 December 2012).

Ministry of Health (MOH). 2007. National Reproductive Health Policy: Enhancing Reproductive Health Status for all Kenyans. Nairobi: $\mathrm{MOH}$.

Ministry of Public Health and Sanitation (MOPHS). 2011. "Statement on hormonal contraception and HIV transmission in women," Standard Newspapers, 9 October, p. 19.

Ministry of Public Health and Sanitation (MOPHS)/Division of Reproductive Health (DRH). 2008. Strategy for Improving the Uptake of Long-Acting and Permanent Methods of Contraception in the Family Planning Program. Nairobi: MOPHS/DRH.

Mwangi, Annie, Charlotte Warren, Nancy Koskei, and Holly Blanchard. 2008. Strengthening Postnatal Care Services Including Postpartum Family Planning in Kenya. Nairobi: Frontiers/ Population Council.

National Council for Population and Development (NCPD), Central Bureau of Statistics (CBS) (Office of the Vice President and Ministry of Planning and National Development), and Macro International (MI). 1999. Kenya Demographic and Health Survey 1998. Calverton, MD: NDPD, CBS, and MI. 
National Council for Population and Development (NCPD)/ Ministry of Planning and National Development. 2000. National Population Policy for Sustainable Development. Nairobi: NCPD.

Republic of Kenya, Ministry of Planning and National Development. 2005. Millennium Development Goals: Needs and Costs. Nairobi: Republic of Kenya, Ministry of Planning and National Development.

Republic of Kenya, Ministry of Public Health and Sanitation (MOPHS) \& Ministry of Medical Services (MOMS). 2009. National Reproductive Health Strategy 20092015. Nairobi: Republic of Kenya, MOPHS \& MOMS.

Republic of Kenya National Council for Population and Development (NCPD) \& Division of Reproductive Health (DRH). Adolescent Reproductive Health and Development Policy. Nairobi: Republic of Kenya NCPD \& DRH

Republic of Kenya/Ministry of Health. 2005. Reversing the Trends: The Second National Health Sector Strategic Plan of Kenya- NHSSP II- 2005-2010. Nairobi: Republic of Kenya/Ministry of Health.
Republic of Kenya/Ministry of Public Health and Sanitation. 2012. The World Breastfeeding Trends Initiative (WBTi): Kenya. Nairobi: Republic of Kenya/Ministry of Public Health and Sanitation.

Shauri, Janet and Janet Vail. 2009. Planning for Introduction of Depo-subQ Provera $104^{\text {TM }}$ in the Uniject Device ${ }^{\circledR}$ : Kenya Initial Country Assessment Report. Seattle: PATH.

Singh, Susheela and Jacqueline E. Darroch. 2012. Adding It Up: Costs and Benefits for Contraceptive Services. New York: Guttmacher and United Nations Fund for Population Activities.

Tepe, M.,, R. Mestad, G. Secura, J.E. Allsworth, T. Madden, and J.F. Peipert. 2010. "Association between tampon use and choosing the contraceptive vaginal ring." Obstetrics and Gynecology 115(4): 735-739. 